\title{
Microalgae community of the Huaytire wetland, an Andean high-altitude wetland in Peru
}

\author{
Comunidade de microalgas do wetland Huaytire, \\ uma área alagada de alta altitude nos Andes peruanos
}

\section{Gian Salazar-Torres and Vera Lúcia de Moraes Huszar}
Departamento de Botânica, Museu Nacional, Universidade Federal do Rio de Janeiro - UFRJ, CEP 20940-040, Rio de Janeiro, RJ, Brazil e-mail: giansato@hotmail.com; vhuszar@gbl.com.br

\begin{abstract}
Aim: The diversity and distribution of microalgae communities in a highaltitude (3,000 to $4,500 \mathrm{~m}$ a.s.l) Andean wetland, regionally known as bofedal, were examined to assess seasonal and spatial patterns. Methods: Samples were taken monthly from June to December, 2008 at 13 stations in the Huaytire wetland (16 54' S and $70^{\circ} 20^{\prime} \mathrm{W}$ ), covering three areas (impacted by urban land use, impacted by camelid pasture, and non-impacted) and three climatologically induced periods (ice-covered, ice-melt and ice-free). Results: A total of 52 genera of algae were recorded. Diatoms were the predominant group in abundance and richness. We found a significantly higher abundance during the ice-melting period, when light exposure and runoff were intermediate, in comparison to the ice-covered (low light and flushing) and ice-free (high light and low runoff) periods. Microalgae abundance was significantly lower in the non-impacted area compared to the sites close to the urban area and to the camelid pastures. Alpha diversity ranged from 8 to 29 genera per sample. High genera exchange was observed throughout the wetland, showing a similar floristic composition (beta diversity $=4 \%)$. Conclusions: We found that diatoms were dominant and adapted to the extreme conditions of the Andean wetland, showing higher abundance during the ice-melt period and in the livestock area. Also, taxa richness was higher in the ice-melt period and in the most-impacted areas.
\end{abstract}

Keywords: high altitude, wetlands, Andes, microalgae, abundance, composition.

Resumo: Objetivo: A diversidade e distribuição da comunidade de microalgas em uma área alagada nos Andes (3.000 a $4.500 \mathrm{~m}$ de altitude), regionalmente conhecido como bofedal, foram examinadas para avaliar seus padróes sazonais e espaciais. Métodos: As amostras foram coletadas, mensalmente, de junho a dezembro de 2008, em 13 estaçóes no bofedal Huaytire $\left(16^{\circ} 54^{\prime} \mathrm{S}\right.$ e $\left.70^{\circ} 20^{\prime} \mathrm{W}\right)$, abrangendo três áreas (impactada por ação urbana, impactada por pastagem de gado camelídeo e área não impactada) e três períodos climatológicos (com cobertura de gelo, em processo de degelo e livre de gelo. Resultados: Um total de 52 gêneros de algas foi registrado. Diatomáceas foi o grupo predominante em abundância e riqueza. Abundância significativamente maior ocorreu durante o período de degelo, quando a exposição à luz e o escoamento foram de intensidades intermediárias, em comparaçáo com o período de cobertura com gelo (pouca exposição à luz e escasso escoamento) e com o período livre de gelo (alta exposição à luz alta e escasso escoamento). A abundância de microalgas foi significativamente menor na área não impactada, em comparação com as áreas, impactada por ação urbana e por pastagem de gado camelídeo. A alfa diversidade oscilou entre 8-29 gêneros por amostra. O intercâmbio de gêneros foi elevado em toda a área alagada, mostrando uma composiçáo florística semelhante (beta diversidade $=4 \%$ ). Conclusáo: Diatomáceas foi o grupo dominante e adaptado às condiçóes extremas nessa área alagada andina, mostrando maior abundância durante o período de degelo e na área de pastagens de gado camelídeo. Além disso, a riqueza de táxons foi maior no período de degelo e, ao contrário do esperado, nas áreas mais impactadas.

Palavras-chave: altitude, zonas húmidas, Andes, microalgas, abundância, composição. 


\section{Introduction}

The knowledge of high-altitude microalgae in the world is derived basically from European alpine lakes and streams (Rott and Pernegger, 1994; Tolotti, 2001). Wetlands in high-altitude temperate regions - peat bogs or Sphagnum bogs - represent one of the major vegetation types, in addition to forests and grasslands (Borics et al., 2003). Peat bogs are often dominated by diatoms, chlorophyceans and cyanobacteria; $\mathrm{pH}$ and electrical conductivity have been noted as the most important ecological variables influencing these communities (Kapetanović and Hafner, 2007). South American high-altitude aquatic systems have been little studied; most of these studies are taxonomic and have been carried out in lakes and streams. In these systems, diatoms are the main algal group (DonatoRondón, 2001; Morales et al., 2007; Díaz-Quirós and Rivera-Rondón, 2004; Sylvestre et al., 2001; Tapia et al., 2003, 2006). In particular, diatoms from high altitude Andean wetlands, are reported mainly as floristic studies which include diatoms from systems located between 4,120 and 4,571 m a.s.l. in Argentina (Maidana and Seeligmann, 2006; Seeligmann et al., 2008; Maidana et al., 2011).

High-altitude wetlands in the Andes exist at the hydrological and altitudinal limits for plant life in the cold and arid high Andean grasslands of Peru, Bolivia, Chile and Argentina (Squeo et al., 2006). In the central Andes ( $\left.16^{\circ} S\right)$, these wetlands occur between 4,000 and 5,000 $\mathrm{m}$ a.s.l., and in the southern parts $\left(27^{\circ} \mathrm{S}\right)$ between 2,000 and 3,000 m a.s.l. (Scott and Carbonell, 1986). These regions have a complex topography and geology, extreme climate conditions with large diel and seasonal variations in temperature and precipitation, very high insolation, and low atmospheric pressure (Jacobsen and Marin, 2008). The native wetland vegetation consists mainly of totorales, which are stands of a perennial reed (Cyperaceae), and bofedales, which are areas of heterogeneous, short and dense grasses, cross-crossed by shallow streamlets (Moreau et al., 2003). High Andean wetlands are sources of life and development for people who live and depend on these ecosystems. We evaluated the seasonal and spatial changes in abundance, richness and composition of the microalgae community in the Huaytire wetland, a high-altitude, low-latitude Andean wetland. As far as we know, this is the first microalgae ecological contribution in this type of extreme environment.

\section{Material and Methods}

Study Site - The study was carried out at the Huaytire wetland, which is located at $4,452 \mathrm{~m}$ a.s.l. in the tropical Andes (16 $54^{\prime} \mathrm{S}$ and $70^{\circ} 20^{\prime} \mathrm{W}$ ), near the Livicalani and Huaytire streams in Tacna, Peru. This wetland encompasses an area of $0.86 \mathrm{~km}^{2}$, and lies within the central Andean dry Puna (Baied and Wheeler, 1993; Otto et al., 2011) (Figure 1). The local climate, following the Köppen system
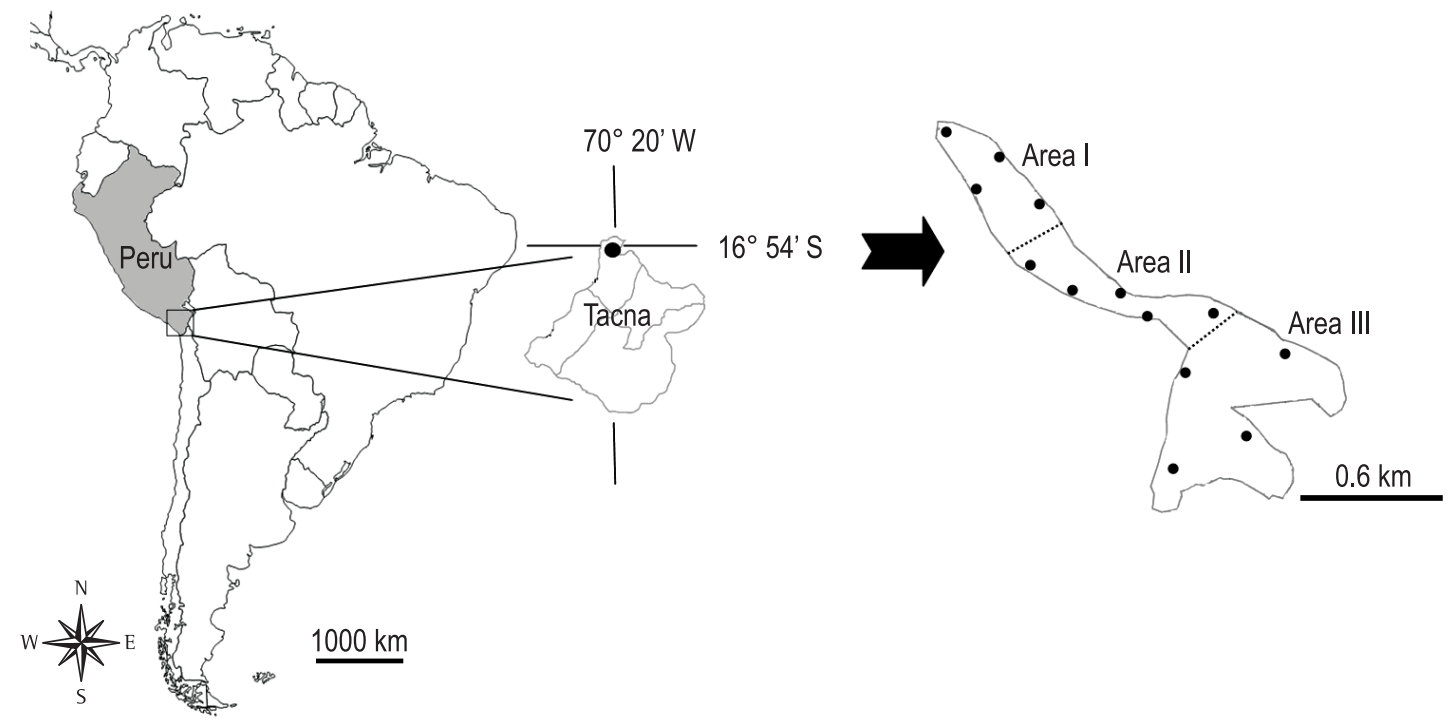

Figure 1. Map and location of the Huaytire wetland (Tacna-Peru) - (marked with a black dot). Area I = upper basin (impacted area); Area II = intermediate, influenced by livestock; Area III = lower basin, the most preserved area, with minimum human and animal influences. 
(1936) and updated by Kottek et al. (2006), is a tundra polar climate (ETk). Daily minimum temperature is generally below $0{ }^{\circ} \mathrm{C}$ and can reach below $-10{ }^{\circ} \mathrm{C}$ during the winter (CONAMA, 2006). The streamlets are shallow ( $-0.5 \mathrm{~m}$ depth). The vegetation is mainly constituted by Juncaceae which are terrestrial or semi-aquatic plants, that occurs in sunny places. Genus Oxychloe, Patosia and Distichia grow at very high elevations, usually between 3,500-4,500 m a.s.l. (Balslev, 1996). Villages located around this type of wetland are sustained by raising camelids livestock (Morris and Panty, 1999).

Sampling, sample analysis and data analysis -Samples were taken monthly, directly from the streams, for microalgae analysis (abundance and composition), from June to December 2008 at 13 sampling stations (91 total samples). Microalgae were fixed with formaldehyde at $4 \%$ final concentration. Electrical conductivity, $\mathrm{pH}$, dissolved oxygen and temperature were measured in situ with a HANNA HI 9813 probe. According to the amount of ice-cover criteria, we recognized three periods: two during the dry season (period A, June to August, ice-covered; and period B, September to October, ice melt), and one in the early rainy season (period C, November to December, ice-free season). Also, three areas were selected according to the land use: area I (upper basin), which is subject to urban influence (impacted area), area II (intermediate, influenced by livestock); and area III (lower basin, the most preserved area, with minimum human and animal influences).

To estimate microalgae abundances, drops of a sample were transferred to a glass slide until they completed $1 \mathrm{~mL}$ (Vollenweider, 1974), and analyzed under an Olympus CX31 light microscope, at 400 $\mathrm{x}$ magnification. Microalgae were identified to the genus level and grouped in taxonomic classes according to Van den Hoek et al. (1997). Genus level was used because identification at the species level is uncertain in this relatively unknown system. Diversity was studied as i) gamma diversity (total pool of genera at all stations and dates); ii) alpha diversity (local genera richness in each sample); and iii) beta diversity (degree of genera turnover among the areas). To ensure that our samples were representative, we also used a rarefaction analysis between samples and number of genera. Intensities of runoff and light exposure were analyzed semi quantitatively, taking into account the ice cover and the seasonal period.

Differences in abundance and richness between areas or periods were determined using KruskalWallis tests. If the differences were significant $(\mathrm{p}<0.05)$, then a post hoc Dunn's test was used to identify differences. Statistical analyses were performed using Stat View ${ }^{\odot} 5.01$ and Sigma Plot v.11.

\section{Results}

Climatological, physical and chemical variables - During the entire year (2008), the total precipitation reached $192 \mathrm{~mm}$ and the mean temperature was $5^{\circ} \mathrm{C}$ (Peru, 2008). The ice-covered and ice-melt periods occurred during the dry season, and were marked by lower temperature and precipitation (Table 1). During the ice-free period, the minimum and mean temperature increased, and the ice melted completely (Table 1). The landscape changed from brownish to greenish with the growing season, mainly Juncaceae.

The depth of the streamlets in this high Andean wetland reached $\sim 0.30 \mathrm{~m}$ during the ice-covered and ice-melt periods, and increased to $\sim 0.50 \mathrm{~m}$ at the beginning of the ice-free period. The median water temperature was higher during the ice-free period $\left(8.7^{\circ} \mathrm{C}\right)$ compared to the ice-covered $\left(5.3^{\circ} \mathrm{C}\right)$ and ice-melt periods $\left(6.3^{\circ} \mathrm{C}\right)(\mathrm{p}<0.001)$ (Table 2$)$.

Low median dissolved oxygen values have been registered (31-38\%), because of high altitude. Dissolved oxygen content during the ice-melt period was higher $(\mathrm{p}=0.018)$ than in the icecovered and ice-free periods (Table 2). Most pH values $(75 \%)$ were circumneutral (6.6-6.8), with no differences among periods $(\mathrm{p}<0.558)$. Electrical conductivity followed the temperature pattern, with

Table 1. Hydrological and climatological features through the seasonal periods in the Huaytire wetland, Tacna-Peru (June-December, 2008). The intensities of flushing and light exposure are semi quantitatively expressed by: X (low), XX (intermediate) and xxx (high). ( $\mathrm{T}=$ temperature; Total $\mathrm{P}=$ precipitation).

\begin{tabular}{lcccccc}
\hline \multicolumn{1}{c}{ Season } & Runoff & Light exposure & $\begin{array}{c}\text { Mean air max. } \\
\left({ }^{\circ} \mathbf{C}\right)\end{array}$ & $\begin{array}{c}\text { Mean air min. } \\
\left({ }^{\circ} \mathbf{C}\right)\end{array}$ & $\begin{array}{c}\text { Mean air mean } \\
\left({ }^{\circ} \mathbf{C}\right)\end{array}$ & $\begin{array}{c}\text { Total P } \\
(\mathbf{m m})\end{array}$ \\
\hline lce-covered & $\mathrm{X}$ & $\mathrm{X}$ & 11 & -9 & 1 & 4.4 \\
Ice-melt & $\mathrm{XX}$ & $\mathrm{XX}$ & 11 & -9 & 1 & 0 \\
lce-free & $\mathrm{XXX}$ & $\mathrm{XX}$ & 10 & -6 & 2 & 32.7 \\
\hline
\end{tabular}


higher median values $\left(80 \mu S . \mathrm{cm}^{-1}\right)$ during the icefree season $(\mathrm{p}<0.021)$.

Microalgae community - In these extreme ecosystems, the predominant microalgae communities are mainly the metaphytic and benthic communities living in the shallow streamlets. During the study period, diatoms were the most abundant algal group, contributing 95\% to the total abundance. Chlorophyceans and cyanobacteria contributed only 3 and $2 \%$ to the total, respectively. Significant differences were found in the total microalgae abundance among the three periods $(\mathrm{p}<0.001)$ and areas $(\mathrm{p}=0.006)$. Abundance was significantly higher during the ice-melt (566 ind. $\mathrm{mL}^{-1}$ ), in comparison to the ice-covered and ice-free seasons (324 and 411 ind. $\mathrm{mL}^{-1}$, respectively) (Figure 2). Significantly higher abundance was also found in the livestock area $\left(508\right.$ ind. $\left.\mathrm{mL}^{-1}\right)$ than in the others (397 and 312 ind. $\mathrm{mL}^{-1}$ ) (Figure 2).

The regional pool of genera (gamma diversity) contained a total of 52 genera (23 diatoms, 17 chlorophyceans, 12 cyanobacteria) (Table 3 ).

Alpha diversity ranged from 8 to 29 genera. sample ${ }^{-1}$ in the different seasons. Genus richness also showed significant differences among periods $(\mathrm{p}<0.001)$ and areas $(\mathrm{p}<0.037)$. Richness was higher in the ice-melt period (20 genera.sample $\left.{ }^{-1}\right)$ than in the ice-covered and ice-free periods (13 and 14 genera.sample ${ }^{-1}$, respectively) (Figure 2). Richness was significantly higher in the urban area (16 genera.sample $\left.{ }^{-1}\right)$, and decreased in the livestock $\left(15\right.$ genera.sample $\left.{ }^{-1}\right)$ and preserved areas (13 genera. sample ${ }^{-1}$ ) (Figure 2). Genus turnover expressed by

Table 2. Median, minimum and maximum (between brackets) values of abiotic variables by season in the Huaytire wetland, Tacna-Peru (June-December, 2008).

\begin{tabular}{lcccc}
\hline \multicolumn{1}{c}{ Season } & Temperature $\left({ }^{\circ} \mathbf{C}\right)$ & Electrical conductivity $(\boldsymbol{\mu S} . \mathbf{c m})$ & Dissolved oxygen (\%) & $\mathbf{p H}$ \\
\hline lce-covered & $5.3(1.5-12.4)$ & $70(50-230)$ & $31.1(10.5-49.9)$ & $6.8(6.0-7.7)$ \\
lce-melt & $6.3(1.4-8.6)$ & $70(40-90)$ & $37.1(14.2-46.3)$ & $6.7(5.4-7.5)$ \\
lce-free & $8.7(7.0-13.4)$ & $80(60-130)$ & $31.5(21.7-49.1)$ & $6.6(5.1-7.6)$ \\
\hline
\end{tabular}
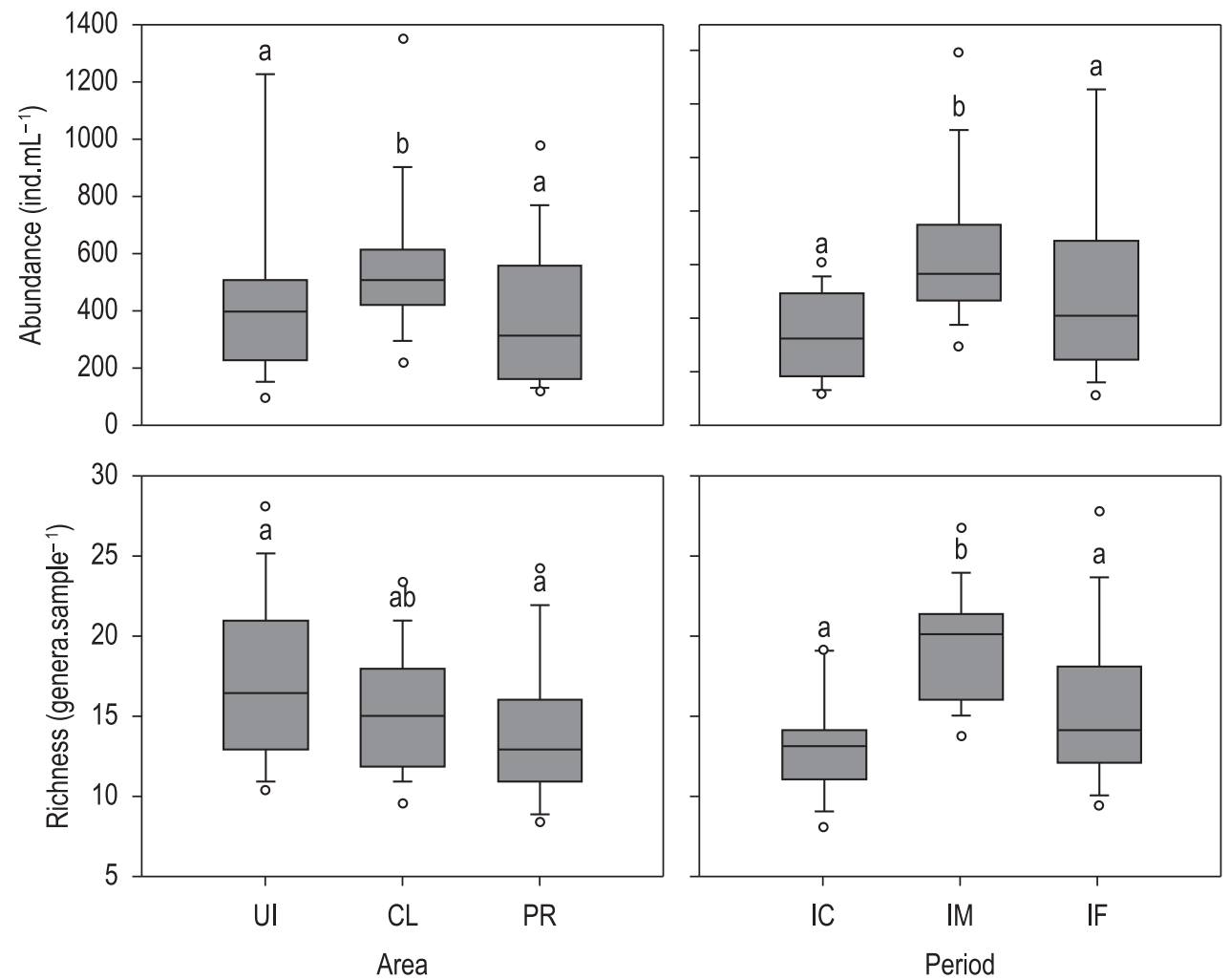

Figure 2. Box-plots of total microalgae abundance (upper panels) and richness of genera (lower panels) by area and period in the Huaytire wetland, Tacna Peru (June-December, 2008). UI = urban influence (impacted), CL = camelids livestock, $\mathrm{PR}=$ preserved (non-impacted), IC = ice-covered, IM = ice-melt, IF = ice-free. Outliers were excluded. Different letters indicate significant statistical differences. 
Table 3. List of microalgae genus and relative abundance (\%) in the Huaytire wetland, Tacna-Peru (June-December, 2008).

\begin{tabular}{|c|c|c|c|c|c|}
\hline Diatoms & $\%$ & Chlorophyceans & $\%$ & Cyanobacteria & $\%$ \\
\hline Cocconeis sp. & 22.46 & Spirogyra sp. & 0.46 & Anabaena sp. & 0.56 \\
\hline Fragilaria sp. & 19.01 & Closterium sp. & 0.39 & Nostoc sp. & 0.30 \\
\hline Pinnularia sp. & 15.43 & Rhizoclonium sp. & 0.39 & Oscillatoria sp. & 0.25 \\
\hline Navicula sp. & 15.09 & Pediastrum sp. & 0.36 & Lyngbya sp. & 0.16 \\
\hline Cymbella sp. & 9.70 & Zygnema sp. & 0.33 & Tolypothrix sp. & 0.09 \\
\hline Gomphonema sp. & 2.36 & Cosmarium sp. & 0.20 & Phormidium sp. & 0.05 \\
\hline Surirella sp. & 1.81 & Scenedesmus sp. & 0.19 & Nodularia sp. & 0.03 \\
\hline Melosira sp. & 1.60 & Ulothrix sp. & 0.15 & Leptolyngbya sp. & 0.00 \\
\hline Stauroneis sp. & 1.46 & Selenastrum sp. & 0.11 & Symploca sp. & 0.03 \\
\hline Neidium sp. & 1.29 & Staurastrum sp. & 0.09 & Gomphosphaeria sp. & 0.01 \\
\hline Rhopalodia sp. & 0.97 & Hyalotheca sp. & 0.08 & Chroococcus sp. & 0.01 \\
\hline Frustulia sp & 0.94 & Oedogonium sp. & 0.07 & Merismopedia sp. & 0.01 \\
\hline Nitzschia sp. & 0.86 & Crucigenia sp. & 0.05 & & \\
\hline Synedra sp. & 0.71 & Ankistrodesmus sp. & 0.04 & & \\
\hline Eunotia sp. & 0.68 & Coelastrum sp. & 0.01 & & \\
\hline Epithemia sp. & 0.50 & Pandorina sp. & 0.01 & & \\
\hline Hantzschia sp. & 0.37 & Euastrum sp. & 0.01 & & \\
\hline Diploneis sp. & 0.07 & & & & \\
\hline Luticola sp. & 0.06 & & & & \\
\hline Amphora sp. & 0.05 & & & & \\
\hline Rhoicosphenia sp. & 0.03 & & & & \\
\hline Cyclotella sp. & 0.03 & & & & \\
\hline Tabellaria sp. & 0.01 & & & & \\
\hline Total (\%) & 95 & & 3 & & 2 \\
\hline
\end{tabular}

beta diversity for the whole data set indicated a very similar composition at all 13 sampling stations (beta diversity $=4 \%)$. The rarefaction curve reached the asymptote at approximately 44 samples from a total of 91 samples (Figure 3).

\section{Discussion}

We found that the microalgae community of this Andean wetland located at tropical latitudes is dominated by diatoms both in richness and abundance showing higher abundance during the ice-melt period and in the area under livestock influence. The wetland, located in the dry Puna in the Andes, has little precipitation, perennial frost, intense solar radiation, and reduced atmospheric oxygen and carbon dioxide concentrations (Baied and Wheeler, 1993). We compared our data to other systems subject to extreme conditions, such as temperate high-altitude wetlands (peat bogs), high-altitude alpine lakes, and systems in polar or subpolar regions, because as far as we are aware, there is no available information on microalgae ecology from the central dry South-American Andean wetlands.

Diatoms were reported as the main algal group in subalpine peat bogs (Kapetanović and
Hafner, 2007). Locally and temporally, diatoms can also constitute an important part of the algal communities in arctic and subarctic regions, because they are adapted to low temperature (Douglas and Smol, 1999). We found remarkable diatom dominance in the Huaytire wetland through the whole study period. Other studies also have reported diatom dominance, for example a small benthic diatom Fragilaria, in a high mountain lake in the northern Canadian Cordillera, where there are cold conditions with long periods of ice cover (KarstRiddoch et al., 2005).

Besides diatoms, chlorophyceans and cyanobacteria are numerous in subalpine peat bogs (Klemenčič et al., 2010); dinoflagellates and chrysophyceans are dominant in the plankton in the Italian Alps, but epilithic communities are dominated by diatoms (Tolotti, 2001). For Andean lakes, in particular, dominances of chlorophyceans and diatoms were reported for Chungará Lake (Chile), Tranca Grande and Titicaca lakes (Peru) (Dorador et al., 2003; Mariano-Astocondor, 2001; Dejoux and Iltis, 1991).

The gamma diversity in the Huaytire wetland is 52 genera. This number is derived through an 


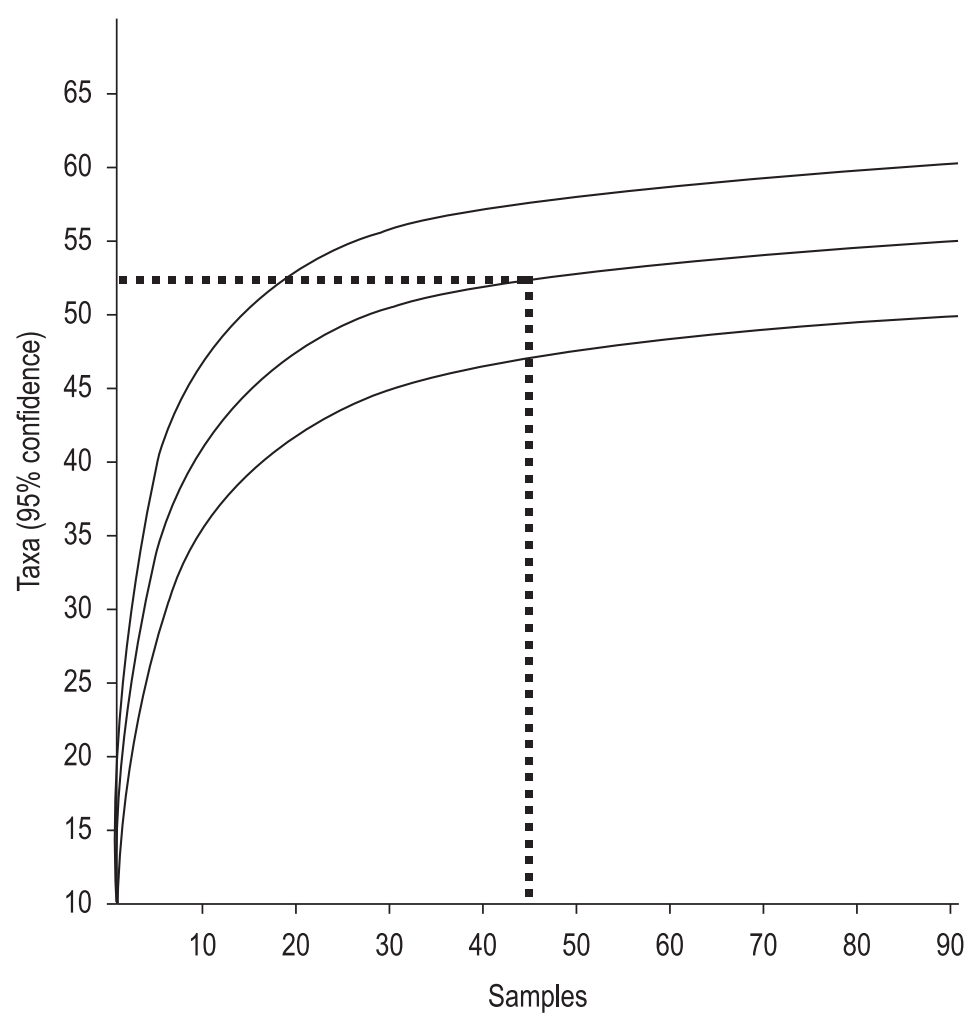

Figure 3. Rarefaction curve and the $95 \%$ confidence interval for microalgae genera in the Huaytire wetland, Tacna Peru, in relation to the number of samples.

effective sampling design; we reached $96 \%$ of the total expected flora in almost half of the samples. Diatoms comprised $42 \%$ of the total genera. The number of 23 diatom genera is similar to the number found in the Pululos wetland (22 genera, Seeligmann et al., 2008), or even higher than in the Puna Nueva wetland (8 genera, Maidana and Seeligman, 2006).

Although we cannot directly compare our data to estimates of abundance and richness from other studies (because the lack of such information in the literature), aquatic high-altitude systems around the world show similar numbers of genera. For example, in high-altitude Swiss springs, 31 genera were recorded (Taxböck and Preisig, 2007); 49 genera were reported in high-altitude Andean Bolivian streams (Morales and Vis, 2007), and 17 genera in a high-altitude stream in the Alps (Rott et al., 2006).

In conclusion, the highest abundance and richness were found during the ice-melt season. Spatially, we found the highest abundance in the livestock area, and higher richness in the two more impacted areas. Diatoms were the predominant group throughout the study. This group seems to be well adapted to the extreme abiotic conditions (low temperature and potentially high light intensity) of this high-altitude Andean wetland.

\section{Acknowledgements}

The study was developed at Botany Laboratory, National University Jorge Basadre Grohmann (Peru), also with the support of Candarave's Municipality (transport to Huaytire Andean wetland). We thank to Professor Pablo Franco (UNJBG) for his laboratory assistance about genus diatoms identification.

\section{References}

BAIED, C. and WHEELER, J. 1993. Evolution of High Andean Puna Ecosystems: Environment, Climate, and Culture Change over the last 12,000 Years in the Central Andes. Mountain Research and Development, vol. 13, p. 145-156. http://dx.doi. org/10.2307/3673632

BALSLEV, H. 1996. Juncaceae. Flora Neotropica Monographs, vol. 68, p. 1-163.

BORICS, G., TÓTHMÉRÉSZ, B., GRIGORSZKY, I., PADISÁK, J., VÁRBÍRÓ, G. and SZABO, S. 2003. Algal assemblage types of bog-lakes in Hungary and their relation to water chemistry, hydrological conditions and habitat diversity. Hydrobiologia, 
vol. 502, p. 145-155. http://dx.doi.org/10.1023/ B:HYDR.0000004277.07316.c8

Comisión Nacional de Medio Ambiente - CONAMA. 2006. Conceptos y criterios para la evaluación ambiental de humedales. Chile: SAG, Ministerio de Agricultura. $81 \mathrm{p}$.

DÍAZ-QUIRÓS, C. and RIVERA-RONDÓN, CA. 2004. Diatomeas de pequeńos ríos andinos y su utilización como indicadoras de condiciones ambientales. Caldasia, vol. 26, p. 81-394.

DONATO-RONDÓN, JC. 2001. Fitoplancton de los lagos andinos del norte de Sudamérica (Colombia): Composición y factores de distribución. Bogotá: Academia Colombiana de Ciencias Exactas, Físicas y Naturales. 232 p.

DORADOR, C., PARDO, R. and VILA, I. 2003. Variaciones temporales de parámetros físicos, químicos y biológicos de un lago de altura: el caso del lago Chungará. Revista Chilena de Historia Natural, vol. 76, p. 15-22. http://dx.doi.org/10.4067/S0716078X2003000100002

DOUGLAS, MSV. and SMOL, JP. 1999. Freshwater diatoms as indicators of environmental change in the High Arctic. In STOERMER, EF. and SMOL, JP., eds. The Diatoms: Applications for the Environmental and Earth Sciences. Cambridge: Cambridge University Press. p. 227-244.

JACOBSEN, D. and MARIN, R. 2008. Bolivian Altiplano streams with low richness of macroinvertebrates and large diel fluctuations in temperature and dissolved oxygen. Aquatic Ecology, vol. 42, p. 643-656. http:// dx.doi.org/10.1007/s10452-007-9127-x

KAPETANOVIĆ, T. and HAFNER, D. 2007. Diatoms of wet habitats in the subalpine belt of Mt. Vranica (Bosnia and Herzegovina). In Proceedings of the 1st Central European Diatom Meeting, 2007. Berlin. p. 73-78. http://dx.doi.org/10.3372/cediatom.115

KARST-RIDDOCH, TL., PISARIC, MFJ. and SMOL, JP. 2005. Diatom responses to 20 th century climaterelated environmental changes in high-elevation mountain lakes of the northern Canadian Cordillera. Journal of Paleolimnology, vol. 33, p. 265-282. http:// dx.doi.org/10.1007/s10933-004-5334-9

KLEMENČIČ, AK., SMOLAR-ŽVANUT, N., ISTENIČ, D. and GRIESSLER-BULC, T. 2010. Algal community patterns in Slovenian bogs along environmental gradients. Biologia, vol. 65, p. 422-437. http://dx.doi.org/10.2478/s11756010-0033-7

KÖPPEN, W. 1936. Das geographisches System der Klimate. In KÖPPEN, W. and GEIGER, R., eds. Handbuch der Klimatologie. Berlin: Gebrüder Borntraeger. p. 1-46.

KOTTEK, M., GRIESER, J., BECK, C., RUDOLF, B. and RUBEL, F. 2006. World map of the KöppenGeiger climate classification updated. Meteorologische
Zeitschrift, vol. 15, p. 259-263. http://dx.doi. org/10.1127/0941-2948/2006/0130

MAIDANA, N. and SEELIGMANN, C. 2006. Diatomeas (Bacillariophyceae) de Ambientes Acuáticos de Altura de la Provincia de Catamarca, Argentina II. Boletín de la Sociedad Argentina de Botánica, vol. 41, p. 1-13.

MAIDANA, N., SEELIGMANN, C. and MORALES, M. 2011. El género Navicula sensu stricto (Bacillariophyceae) en humedales de altura de Jujuy, Argentina. Boletín de la Sociedad Argentina de Botánica, vol. 46, p. 13-29.

MARIANO-ASTOCONDOR, M. 2001. Composición y estructura de la comunidad fitoplanctónica en la laguna Tranca Grande (Junín, Perú). Revista Peruana de Biología, vol. 8, p. 2.

MORALES, E. and VIS, M. 2007. Epilithic diatoms (Bacillariophyceae) from cloud forest and alpine streams in Bolivia, South America. Proceedings of the Academy of Natural Sciences, vol. 156, p. 123-155.

MORALES, E., VIS, M., FERNÁNDEZ, E. and KOCIOLEK, JP. 2007. Epilithic diatoms (Bacillariophyta) from cloud forest and alpine streams in Bolivia, South America II: A preliminary report on the diatoms from Sorata, La Paz. Acta Nova, vol. 3, p. 3-4.

MOREAU, S., BOSSENO, R., GU, XF. and BARET, F. 2003. Assessing the biomass dynamics of Andean wetland and totora high-protein wetland grasses from NOAA/AVHRR. Remote Sensing of Environment, vol. 85, p. 516-529. http://dx.doi.org/10.1016/ S0034-4257(03)00053-1

MORRIS, M. and PANTY, O. 1999. Espacio y Conciencia Geográfica en Tacna. Tacna: Tercer Milenio, 110 p.

OTTO, M., SCHERER, D. and RICHTERS, J. 2011. Hydrology differentiation and spatial distribution of high altitude wetlands in a semi-arid Andean region derived from satellite data. Hydrology and Earth System Sciences, vol. 15, p. 1713-1727. http://dx.doi. org/10.5194/hess-15-1713-2011

Peru. Servicio Nacional de Meteorología e Hidrología - SENAMHI. 2008. Datos Históricos (2008). Oficina de estadística. Available from: <http:// www.senamhi.gob.pe/>. Access in: Nov. 2010.

ROTT, E. and PERNEGGER, L. 1994. Epilithic cyanophytes form soft-water mountain lakes in the central Alps (Austria) and in the Pirin Mountains (Bulgaria) with special reference to taxonomy and vertical zonation. Algological Studies, vol. 105, p. 249-264.

ROTT, E., CANTONATI, M., FÜREDER, L. and PFISTER, P. 2006. Benthic algae in high altitude streams of the Alps - a neglected component of aquatic biota. Hydrobiologia, vol. 562, p. 195-216. http://dx.doi.org/10.1007/s10750-005-1811-z 
SCOTT, D. A. and CARBONELL, M. 1986. A Directory of Neotropical Wetlands. Cambridge: IUCN Conservation Monitoring Centre. 684 p.

SEELIGMANN, C., MAIDANA, N. and MORALES, M. 2008. Diatomeas (Bacillariophyceae) de humedales de altura de la Provincia de Jujuy-Argentina. Boletín de la Sociedad Argentina de Botánica, vol. 43, p. 1-17.

SQUEO, F., WARNER, B., ARAVENA, R. and ESPINOZA, D. 2006. Bofedales: High altitude peatlands of central Andes, La Serena, Chile. Revista Chilena de Historia Natural, vol. 79, p. 245-255. http://dx.doi.org/10.4067/S0716078X2006000200010

SYLVESTRE, F., SERVANT-VILDARY, S. and ROUX, M. 2001. Diatom-based ionic concentration and salinity models from the south Bolivian Altiplano $\left(15-23^{\circ} \mathrm{S}\right)$. Journal of Paleolimnology, vol. 25, p. 279-295. http://dx.doi. org/10.1023/A:1011157611619

TAPIA, PM., FRITZ, SC., BAKER, PA., SELTZER, GO. and DUNBAR, RB. 2003. A late Quaternary diatom record of tropical climatic history from Lake Titicaca (Peru and Bolivia). Palaeogeography, Palaeoclimatology, Palaeoecology, vol. 194, p. 139-164. http://dx.doi.org/10.1016/S0031-0182(03)00275-X
TAPIA, PM., FRITZ, SC., BAKER, PA., SELTZER, GO., RODBELL, DT. and METIVIEZ, SP. 2006. Contemporary distribution and late Quaternary stratigraphy of diatoms in the Junin Plain, Central Andes, Peru. Boletín de la Sociedad Geológica del Peru, vol. 101, p. 19-42.

TAXBÖCK, L. and PREISIG, H. 2007. The diatom communities in Swiss springs: A first approach. In Proceedings of the 1st Central European Diatom Meeting, 2007. Berlin. p. 163-168. http://dx.doi. org/10.3372/cediatom. 134

TOLOTTI, M. 2001. Phytoplankton and littoral epilithic diatoms in high mountain lakes of the Adamello-Brenta Regional Park (Trentino, Italy) and their relation to trophic status and acidification risk. Journal of Limnology, vol. 60, p. 171-188. http:// dx.doi.org/10.4081/jlimnol.2001.1.171

VAN DEN HOEK, C., MANN, DG. and JAHNS, HM. 1997. Algae - An Introduction to Phycology. Cambridge: Cambridge University Press. 627 p.

VOLLENWEIDER, RA. 1974. A Manual on Methods for Measuring Primary Production in Aquatic Environments. 2nd ed. London: Blackwell Scientific Publications. IBP Handbook no. 12. 224 p.

Received: 16 April 2012 Accepted: 22 November 2012 